\title{
Research on the Effectiveness of the "Cooperative - Guidance" Teaching Method in the Cultivation of Basketball Students' Team Consciousness
}

\author{
Xin Wei \\ Xincheng Street 2888, Jilin Agricultural University, Changchun, Jilin Province 130118, PR China \\ Department of Sports and Teaching, Jilin Agricultural University \\ 1005488505@qq.com
}

\begin{abstract}
Keywords: College; Basketball elective course; Cooperation; Guidance; Cooperation spirit; Innovation consciousness
\end{abstract}

\begin{abstract}
This paper focuses on the application of "cooperative-guidance" teaching method in tactical teaching of basketball selective course in colleges and universities, which can give full play to the role of education in physical education. The aim of this study is to cultivate the basketball tactical awareness and team consciousness of students in the teaching activities of the effect to the whole physical and mental education, training students to adapt to the future social reality to innovation and cooperation the spirit of improving students' ability in the fierce competition of the modern society and based on survival.
\end{abstract}

\section{Introduction}

Basketball, as a collective confrontation project with a wide range of popularization, is popular with people for its ornamental and entertaining characteristics. Basketball has become a campus culture because of its small environmental constraints and easy acceptance. In basketball course students can release the pressure through the fierce confrontation and run quickly, alleviate the heavy academic students bring to the overwrought atmosphere, students can also get to know more friends through basketball. Therefore, basketball is the majority of students love. As an important part of basketball course of PE elective courses, the last link in school physical education plays an important role of college sports, it is an important means of cultivating college students' sense of lifelong physical education, is to cultivate the skills of students "movement, effective method of moving interest", is an effective means of sports in college students in the future life of an important tool to extend. In order to meet the teaching method reform proposed by the Ministry of Education, the two kinds of new teaching methods at the present stage are used in the teaching of offensive tactics in the college basketball selective course, namely, the cooperative-guidance teaching method. The students in the unity and cooperation, self-innovation under the good atmosphere to effectively master the basic principles of basketball offensive tactics, learn the right time and space in the rational use of technical and tactical at the same time, the students team spirit and self-awareness has been greatly improved .

\section{The Present Situation of College Students}

Because the country's family planning policy makes the proportion of the only - child of common college students increase, the increase of the only - child has brought a great test to the education of the modern common colleges and universities. Most of the only-child by the elders of the favor, to do things of self-centered, rarely consider the feelings of others, rarely from other people's point of view, don't know how to share happiness and pain and the lack of communication the ability and skill. The only child's life is to spent most of their time with the elders, the lack of friends, the contact time between peers and even making some children has fear of communication with autistic tendency. Children don't have siblings and companionship. Children lack of games and collective activities with their partners are not easy to cultivate the spirit of collaboration and lack of innovation consciousness. Therefore, the social adaptability is poor and easy to form 
eccentric and lacking enthusiasm. In addition, after three years of high school "closed" learning, so that modern college students lack of cooperation with others the time and opportunity, resulting in a modern university students to self-centered, will not cooperate unwilling to cooperate adverse situation. Therefore, university education not only to cultivate the ability of students to serve the community, but also to enable students to develop a complete healthy personality and independent survival and adaptability to society. University physical education as the last link of school sports, and its unique advantages in the overall quality of college students play an important role in the process of training. To make this advantage to continue, to maximize, the college sports workers to assess the situation, advancing with the times, good at reform, with the most innovative and most effective teaching methods to serve the college physical education, the most effective way to improve modern university students unfavorable situation.

\section{"Cooperative-Guidance" Teaching Method in the Teaching of Basketball Offensive Tactics Can Effectively Improve the Current Situation of the Disadvantaged College Students}

"Cooperative-guidance" teaching method combines the advantages of two kinds of excellent teaching methods, teaching in basketball offensive tactics through group teaching, group practice, emphasizing the unity of the student team collaboration, self-innovation, learning, using and between groups of the fierce competition and other forms. It will be the unity of the spirit of college students, cooperation, awareness of education into the most basic offensive tactics in the teaching process, that is, to enable students to master the theory of basketball offensive tactics and practical use, but also to the contemporary college humanistic spirit and improve the purpose of college students' social adaptability. In addition, through the teacher 's language guidance and the scene set, make full use of questions, students to think independently, group discussions, teacher Q \& A, practical application of thinking-oriented teaching methods to improve student understanding of offensive tactics, active learning ability, Train students to think independently, the courage to innovate, to develop divergent thinking way of thinking.

\section{"Cooperative-Guidance" Teaching Method in Basketball Offensive Tactics Teaching Concrete Implement}

Teaching Groups. To classify the students in the experimental class is the prerequisite to ensure the teaching effect. In order to ensure the balance among the groups, the groups are divided into five groups with the equal number according to the pre-class physical quality and technical level test. This collocation is more conducive to the implementation of teaching experiments, which is good for students to help each other, and jointly improve.

Excitation Mechanism. The language of the students on the incentive, the group elected within the team leader, led by the head of the organization and the daily practice. Usual grades in a group as a unit to calculate, emphasizing the students' collective sense of honor.

Specific Operations. After the completion of the teaching group, the experimental class each group to carry out non-discriminatory common teaching, collective teaching new teaching content. After the end of the group, the group was divided into groups to practice. During the training process, the problems were found and the questions were raised. The team members were summarized and presented to the teachers who can give right answers. After the practice, the teacher arranges the questions according to the content of the teaching, guiding the students to think and advocates the students to innovate their ideas and brainstorming to find out various ways to solve the problem. After the problem is solved, the students carry out the concrete implementation of the tactics in order to achieve the purpose of verification. At the same time, the teacher can find out the practical problems encountered in the practice process and summary after-class.

In addition. The final tactics will ultimately be used in combat, so that the tactics can combat the main teaching, so basketball offensive tactics in the teaching process, the student's actual game is very important, which should make full use of the students' psychological, teaching, 
supplemented by practice in the teaching process, the practical application. Teachers' instruction, answering questions by students teaching the game, the main spot application.

\section{Results and Analysis}

In the last two classes of each semester, students will be evaluated in the teaching competition. In the course of the evaluation, the students were randomly divided into groups. The course of the competition was recorded, and then the number of offensive tactics, the correct use of offensive tactics and the effective use of offensive tactics were counted. After the one-year experimental teaching, the students were surveyed again, and the students' team-consciousness and tactical innovation spirit were tested and compared with that of the control class.

The "cooperative-guidance" teaching method is used to group the cooperative teaching method in the application of the tactical teaching of the basketball selective course in colleges and universities, and to carry on the collective examination in the group, the teaching competition of the practice and teaching process. students in all courses in addition to the assessment on the outside as a group. Teaching process and teaching methods and ways also emphasize teamwork, teachers in the problem set also stressed the group brainstorming, which is aim to the students to create a full atmosphere of cooperation and cultivate students teamwork consciousness. The results showed (Table-1), the awareness of the team in the experiment group that is used the ways of "cooperative-guidance" teaching method was significantly higher than that in the general teaching group, and the students in the experimental class were significantly higher than those in the control group after a year of teaching to fully understand the collective basketball project team spirit requirements, as well as the importance of teamwork.

Table 1-1 Comparative analysis of teamwork awareness between the experimental class and the control class

\begin{tabular}{|c|c|c|c|}
\hline Group & $\begin{array}{c}\text { Teamwork Awareness Test Results } \\
\text { (The average score) }\end{array}$ & $\begin{array}{c}\mathrm{T} \\
\text { value }\end{array}$ & $\begin{array}{c}\mathrm{P} \\
\text { value }\end{array}$ \\
\hline Experimental class & 69.81 & \multirow{2}{*}{2.83} & \multirow{2}{*}{$<0.01$} \\
\hline Contrast Class & 64.74 & & \\
\hline \multicolumn{4}{|c|}{$\begin{array}{l}\text { In addition, any kind of tactics isn't definitely by one person who can complete it, tactical itself } \\
\text { is a collaborative process, the same offensive tactics correct and effective use of solidarity among } \\
\text { students is the result of joint efforts that is a kind of cultivation of students' unity spirit. The } \\
\text { application of "cooperation-guidance" teaching method in offensive tactics teaching emphasizes } \\
\text { teamwork more effectively and cultivates students' team spirit more effectively. }\end{array}$} \\
\hline
\end{tabular}

\section{Conclusion}

Our country is in the primary stage of socialism, China's higher education to serve the development of social productive forces, for all trades and industries to cultivate innovative spirit to adapt to the social development of new talent. In addition, Marx's human nature includes two meanings: one is that people are the sum of all social relations; the other is that its fundamental attribute is the reality and sociality. That is the sum of all kinds of social relations can not exist alone, everything cannot be divorced from the others alone, in the modern competitive society is even more so in the contemporary spirit of cooperation for the contemporary college students is particularly important. The application of "cooperative - guidance" teaching method in college basketball elective course in tactics teaching, can give full play to the educational function of 
physical education, the cultivation of basketball tactical awareness and team consciousness of students in the teaching activities of the effect to the whole physical and mental education, training students to adapt to the future social reality to innovation and cooperation the spirit of improving students' ability in the fierce competition of the modern society and based on survival.

\section{Reference}

[1] Wu Koulong. Basketball tactics teaching of College Physical Education Research [J]. Journal of Sports \& Science, 2007, (11).

[2] Tan Wenhui. Experimental research on the teaching method of hierarchical grouping in basketball teaching [J]. Hubei sports science and technology, 2008, (1)

[3] Xue Jing. Study on the application of cooperative learning in physical education [J]. Social Science Forum, 2006, (9)

[4] Zhao Xianfa. Experimental Research on the Application of Cooperative Teaching Method in Basketball Elective Course in Colleges and Universities. Master Graduation Thesis of Beijing Sport University, 2004.10.

[5] Lin Songying. The practice of cooperative learning in physical education. Journal of Ningde Teachers College (NATURAL SCIENCE EDITION), 2007.5.

[6] Siedentop, D\&Tannehill. Developing teaching skill in physical education. Mountain View, 2000.

[7] Silverma. Research on teaching in physical education. Research Quarterly for Exercise and Sport, 1991, (4).

[8] Glasser. "choice theory" and students success [J].The Education Digest,1997(63). 